\title{
Effect of nutrient supply on the biomass structure of planktonic communities: an experimental test on a Mediterranean coastal community
}

\author{
Carlos M. Duarte ${ }^{1, *}$, Susana Agustí ${ }^{1}$, Josep M. Gasol ${ }^{2}$, Dolors Vaqué ${ }^{2}$, \\ Evaristo Vazquez-Dominguez ${ }^{2}$ \\ ${ }^{1}$ Instituto Mediterráneo de Estudios Avanzados (IMEDEA), CSIC-Universitat de les Illes Balears, c/ Miguel Marqués, 21, \\ 07190 Esporles (Mallorca), Spain \\ ${ }^{2}$ Institut de Ciencies del Mar, CSIC, Passeig Joan de Borbó s/n, 08039 Barcelona, Spain
}

\begin{abstract}
The hypothesis that increasing nutrient supply increases the biomass of autotrophs proportionately more than the biomass of heterotrophs was tested by increasing $(0,1-, 2-, 4-, 8-$, and $16-$ fold over the background loading of $5 \mathrm{mmol} \mathrm{N} \mathrm{m}^{-2} \mathrm{~d}^{-1}, 1.6 \mathrm{mmol} \mathrm{Si} \mathrm{m} \mathrm{d}^{-1}$, and $0.25 \mathrm{mmol} \mathrm{P} \mathrm{m}^{-2} \mathrm{~d}^{-1}$ ) the addition of nutrients to large (33000 l) mesocosm units enclosing an oligotrophic coastal Mediterranean planktonic community. Autotrophic plankton biomass increased 50-fold along the range of nutrient inputs, whereas heterotrophic biomass increased only 10-fold. Heterotrophic biomass increased as the $1 / 5$ power of the increase in the biomass of autotrophs, implying that the ratio of heterotroph to autotroph biomass (HB/AB ratio) declined rapidly as the biomass of autotrophs increases with increasing nutrient inputs. The biomass distribution within the community shifted from an 'inverted pyramid' distribution, involving greater biomass of heterotrophs than that of autotrophs, at low nutrient inputs, to the conventional 'upward' pyramid pattern, where the biomass of autotrophs exceeds that of consumers, at the highest nutrient inputs. This shift stabilized after $4 \mathrm{~d}$, and the pyramids remained quite constant for the rest of the experiment. The experimental test presented supports the hypothesis that the relative biomass distribution between heterotrophs and autotrophs is regulated by nutrient supply.
\end{abstract}

KEY WORDS: Mediterranean $\cdot$ Plankton $\cdot$ Biomass distribution $\cdot$ Autotrophs $\cdot$ Heterotrophs $\cdot$ Nutrient inputs $\cdot$ Mesocosm

Resale or republication not permitted without written consent of the publisher

\section{INTRODUCTION}

Planktonic communities deviate from the general pattern of biomass distribution in ecosystems, which is characterized by a pyramidal shape in which the biomass of primary producers is much greater than that of consumers at increasingly high trophic levels (Elton 1927). In contrast, planktonic communities often present roughly equal biomasses at different trophic levels (square biomass distribution) or even an inverted pyramid shape, as observed in many oligotrophic eco-

*E-mail: cduarte@uib.es systems (e.g. Holligan et al. 1984). These anomalous distributions reflect an increased dominance of heterotrophic biomass in increasingly unproductive environments (Gasol et al. 1997, Uye et al. 1999). The combined biomass of bacteria, protists and zooplankton tends to exceed that of autotrophs in most marine environments (e.g. Holligan et al. 1984, Alcaraz et al. 1985, Simon et al. 1992), but the biomass of planktonic heterotrophs may exceed that of autotrophs by as much as an order of magnitude in highly oligotrophic ecosystems (Gasol et al. 1997). The high biomass of heterotrophs in unproductive marine ecosystems is associated with significant heterotrophic metabolism comparable 
to, and often exceeding, primary production (Duarte \& Agustí 1998), and has, therefore, important consequences for the functioning of marine ecosystems.

The pattern of declining ratios of heterotrophic to autotrophic biomass in increasingly productive waters suggests that the biomass distribution of planktonic communities may be regulated by nutrient supply. However, this simple pattern may be partially the result of differences between coastal (often more productive) and oceanic communities used in comparative analyses (Gasol et al. 1997) or in the descriptive work (Uye et al. 1999). In addition, the relatively high biomass of heterotrophs in oligotrophic systems maintains autotrophic biomass at low levels, leading to the fast turnover of the autotrophs there (Gasol et al. 1997), which are dominated by small, pico-sized algae (Buck et al. 1996). Therefore, whether changes in the biomass distribution of marine planktonic communities with increasing productivity are the result of differences in nutrient supply, the result of differences in grazing pressure, or are due to other factors cannot be resolved with previous comparative analyses.

Here we experimentally tested the hypothesis that increasing nutrient supply will lead to a shift in the biomass distribution, by increasing the biomass of autotrophs proportionately more than the biomass of heterotrophs, from an inverted pyramid to an upright pyramid pattern. We did so on the basis of an experiment assessing the response of an oligotrophic coastal Mediterranean planktonic community enclosed in large (33000 l) mesocosms to increasing nutrient supply. Although our experiment tested for the effect of nutrient supply on biomass community structure, we did not test whether this is the only mechanism or the one that is dominant in the field.

\section{METHODS}

The experiment was conducted between June 18 and July 8, 1997, near the coastal town of Blanes (NE Spain). The experimental design involved a gradient of nutrient additions to mesocosms following a geometric series of nutrient inputs centered at the nutrient loading calculated for the Bay of Blanes, estimated to be about $5 \mathrm{mmol} \mathrm{N} \mathrm{m}^{-2} \mathrm{~d}^{-1}$ in summer (Duarte et al. 2000), hereafter referred to as a 'business as usual' control. Phosphorus and silicon were added to maintain their average summer stoichiometry with nitrogen in the sedimentary flux (20N:7Si:1P, Duarte et al. 2000). Nitrogen was added as ammonium, the dominant form of summer nitrogen inputs to the Bay of Blanes.

Experimental design and operation. We used a series of 7 large (nominal and effective volume 50 and $33 \mathrm{~m}^{3}$, respectively) mesocosms, consisting of $14 \mathrm{~m}$ tall bags with a $4.2 \mathrm{~m}^{2}$ cross-sectional area. One of the units (which received twice the 'business as usual' nutrient loading), was found to be damaged $4 \mathrm{~d}$ prior to the end of the experiment. Nutrients were added to the mesocosms on alternate days, following the collection of samples, with solutions of $\mathrm{NH}_{4} \mathrm{Cl}, \mathrm{KH}_{2} \mathrm{PO}_{4}$, and $\mathrm{Na}_{2} \mathrm{SiF}_{6}$, in seawater. The nutrient additions included a treatment equivalent to the 'business as usual' control, a treatment equivalent to half of that nutrient input, and enriched nutrient additions equivalent to 2-, 4-, 8- and 16 -fold the 'business as usual' control. We also used a mesocosm to which no nutrients were added. The nutrient input to this mesocosm unit, derived from wet and dry atmospheric deposition, was determined from shortterm nutrient mass balances to be $\sim 0.005 \mu \mathrm{M} \mathrm{N} \mathrm{d}^{-1}$ (Duarte et al. 2000). Additional details on the experimental design are reported by Duarte et al. (2000). Integrated water samples ( 0 to $13 \mathrm{~m}$ ) to determine nutrient concentrations and microplankton biomass were collected on alternate days at 07:00 $\mathrm{h}$ and transported within $30 \mathrm{~min}$ to the laboratory.

Phytoplankton abundance and biomass. The abundance of autotrophic plankton was estimated using flow cytometry for picoplankton, epifluorescence microscopy for nanoflagellates, and an inverted microscope on concentrated samples for microphytoplankton. Fresh subsamples of water from the different experimental bags were filtered through a $50 \mu \mathrm{m}$ mesh, maintained in the dark and analysed in a FACSCalibur (Becton Dickinson) flow cytometer for the quantification of picophytoplanktonic cells (Agawin et al. 2000, in this issue). Cell volume was estimated from the mean cell diameter, calculated from the mean forward scattering (FSC) signal of the populations using a calibration curve developed using cultured organisms and fluorescent beads of different diameters (FluoSpheres Size Kit No. 2, Molecular Probes Co.). Nanophytoplankton samples, preserved in glutaraldehyde ( $1 \%$ final concentration), were filtered through $0.6 \mu \mathrm{m}$ Nuclepore filters, counted and measured at $\times 1000$ under an epifluorescence microscope. Microphytoplanktonic samples ( 0.5 to 21 , depending on density), preserved in glutaraldehyde, were pre-concentrated into $10 \mathrm{ml}$ using a Millipore concentrator chamber with $5 \mu \mathrm{m}$ pore size membranes and were enumerated at 200x and 320x magnification under an inverted microscope (Duarte et al. 2000). Cell volume was calculated from microscopic measurements of the linear dimensions of the cells, and used to calculate phytoplankton biovolume as the product of cell abundance and cell volume. Autotrophic carbon was calculated from biovolume estimates by assuming cyanobacteria to contain $0.123 \mathrm{pg} \mathrm{C} \mathrm{mm}^{-3}$ (Waterbury et al. 1986), and using the equations provided by Strathmann (1967) for the other groups. 
Heterotroph abundance and biomass. A $100 \mathrm{ml} \mathrm{sub-}$ sample from each mesocosm was preserved with cold glutaraldehyde (1\% final concentration) for DAPI counts of heterotrophic nanoflagellates by epifluorescence microscopy (Porter \& Feig 1980). Subsamples of 10 to $15 \mathrm{ml}$ were filtered, within $24 \mathrm{~h}$ of collection, through $0.6 \mu \mathrm{m}$ black polycarbonate filters to collect nanoflagellates. These were stained with $0.1 \mu \mathrm{g} \mathrm{ml} \mathrm{m}^{-1}$ final DAPI concentration for $5 \mathrm{~min}$ and mounted on microscope slides with non-fluorescent oil. The filters were kept frozen until microscopial inspection which occurred within 1 mo of sampling. At least 100 cells were counted and measured in each sample. We distinguished colorless nanoflagellates, which we assumed were heterotrophic, from pigmented or flagellates with chloroplasts, which we assumed to be phototrophic. However, we are aware that some of the nanoflagellates that we considered phototrophic could have been mixotrophic. Heterotrophic nanoflagellate biovolume was calculated as the product of cell abundance and cell volume, estimated from cell dimensions by approximation to the nearest geometrical figure. Carbon biomass was estimated assuming a carbon content of $0.22 \mathrm{pg} \mathrm{C} \mathrm{m}^{-3}$ (Børsheim \& Bratbak 1987).

Ciliate abundance was examined in single $100 \mathrm{ml}$ samples, which were preserved in a $1 \%$ final concentration of acidic Lugol's solution, and sedimented in $100 \mathrm{ml}$ chambers for at least $48 \mathrm{~h}$ before enumeration, at $200 \times$ or $400 \times$ magnification, using an inverted microscope attached to a video camera. Enumeration and sizing were performed from the images recorded on the video tape. Ciliate average size was determined after measuring all cells recorded per sample (from 50 to 200 cells). Ciliate cell volume was measured by approximation to the nearest geometric figure, and ciliate biovolume was calculated as the product of cell abundance and cell volume. To avoid the probable underestimation of ciliate volume due to fixation with Lugol's solution (Leaky et al. 1994, Stoecker et al. 1994), the average cell volume was converted to carbon equivalents using the factor experimentally derived for fixed (with Lugol's solution) marine oligotrichs of $0.2 \mathrm{pg} \mathrm{C} \mathrm{mm}^{-3}$ (Putt \& Stoecker 1989), except for tintinnid carbon, which was estimated using the experimentally derived factor of $0.053 \mathrm{pg} \mathrm{C} \mathrm{mm}^{-3}$ of lorica volume (Verity \& Langdon 1984).

A $1.2 \mathrm{ml}$ subsample for bacterial counts was preserved with $1 \%$ paraformaldehyde $+0.05 \%$ glutaraldehyde (final concentration), frozen in liquid nitrogen and later stored at $-70^{\circ} \mathrm{C}$ freezer to determine bacterial abundance and relative size by flow cytometry. The samples were thawed, stained for a few minutes with Syto13 (Molecular Probes) at $2.5 \mu \mathrm{M}$ and run through a flow cytometer (Gasol \& del Giorgio 2000). We used a Becton \& Dickinson FACScalibur bench machine with a laser emitting at $488 \mathrm{~nm}$. Samples were run at low speed (approx. $18 \mu \mathrm{l} \mathrm{min}{ }^{-1}$ ) and data were acquired in log mode until around 10000 events had been recorded. We added $10 \mu \mathrm{l}$ per sample of a $10^{6} \mathrm{ml}^{-1}$ solution of yellow-green $0.92 \mu \mathrm{m}$ latex beads (Polysciences) as an internal standard. Bacteria were detected by their signature in a plot of side scatter (SSC) versus green fluorescence (FL1) as suggested by del Giorgio et al. (1996). The average fluorescence of the bacterial population, as normalized to that of the beads, is a rough approximation of bacterial size (Gasol \& del Giorgio 2000). These authors show that there is a relatively good relationship between relative FL1 and size (range analysed: 0.028 to $0.072 \mu \mathrm{m}^{3}$ ) in which:

$$
\begin{aligned}
\text { Size }\left(\mu \mathrm{m}^{3}\right) & =7.5 \times 10^{-3}+0.11 \text { relative FL1 } \\
\left(\mathrm{N}=20, \mathrm{R}^{2}\right. & =0.66)
\end{aligned}
$$

Photosynthetic prokaryotes were easily differentiated from non-photosynthetic prokaryotes by examining plots of FL1 versus FL3 (red fluorescence). Bacterial size was converted to weight using the carbon to volume relationship derived by Norland (1993) from the data of Simon \& Azam (1989):

$$
\text { pg C cell }{ }^{-1}=0.12 \times\left(\mu \mathrm{m}^{3} \operatorname{cell}^{-1}\right)^{0.7}
$$

Metazoan zooplankton was sampled by vertical hauls with a $25 \mathrm{~cm}$ diameter net ( $45 \mu \mathrm{m}$ mesh size). The samples were preserved in $4 \%$ formalin, and the organisms were enumerated and measured under a dissecting microscope. Conversions of biovolume to carbon were obtained using the regressions described by Cushing et al. (1958).

\section{RESULTS}

Increased nutrient inputs resulted in an increased autotrophic plankton biomass, reaching, at the highest nutrient inputs, values 50-fold greater $\left(32.3 \mu \mathrm{mol} \mathrm{C} \mathrm{^{-1 } )}\right.$ than those of the community initially enclosed $(0.71 \pm$ $0.065 \mu \mathrm{mol} \mathrm{C}^{-1}$ ). The increased autotrophic biomass was largely contributed by microphytoplankton, despite the initial dominance of picophytoplankton (Fig. 1). In fact, picophytoplankton (Synechoccocus sp.) also showed an initial response to increased nutrient inputs, but this response was much weaker than the subsequent response of the microphytoplankton (Fig. 1). The modest initial response of heterotrophic bacteria was followed by a more sustained biomass development, as observed also for heterotrophic nanoflagellates (Fig. 2). Ciliates, whose biomass was negligible during the study, showed no response to increased nutrient inputs, and neither did mesozooplankton, which dominated the heterotrophic biomass at the onset of the experiment (Fig. 2). 
Heterotrophic biomass showed a much more modest increase in response to enhanced nutrient inputs than autotrophic biomass did, increasing from an initial biomass of $1.39 \pm 0.11 \mu \mathrm{mol} \mathrm{C} \mathrm{^{-1 }}$ to a maximum biomass of

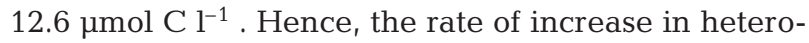
trophic biomass was far slower than that of autotrophic biomass. The changes in heterotrophic and autotrophic biomass in the mesocosms were strongly correlated. Autotrophic biomass accounted for about $50 \%$ of the differences in heterotrophic biomass among the mesocosms with time $\left(\mathrm{R}^{2}=0.46, \mathrm{p}<0.00001\right)$. The rela-

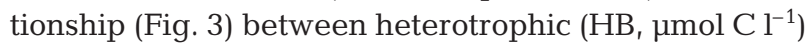
and autotrophic biomass $\left(\mathrm{AB}, \mu \mathrm{mol} \mathrm{C}^{-1}\right.$ ) was best described by the power equation:

$$
\mathrm{HB}=79.4 \mathrm{AB}^{0.20 \pm 0.02}
$$

which indicates that the biomass of heterotrophic organisms increases as the $1 / 5$ power of the increase in the biomass of autotrophs. This non-linear relationship implies that the ratio of heterotroph to autotroph biomass (HB/AB ratio) should decline rapidly as the biomass of autotrophs increases with increasing nutrient inputs, as confirmed by the examination of the data (Fig. 4). The decline in the ratio of heterotroph to autotroph biomass with increasing autotroph biomass (HB/AB) was described by the regression equation:

$\mathrm{HB} / \mathrm{AB}=2.08 \mathrm{AB}^{-0.77 \pm 0.038}\left(\mathrm{R}^{2}=0.85, \mathrm{p}<0.00001\right)$

which indicated that the $\mathrm{HB} / \mathrm{AB}$ ratio declined as the $-3 / 4$ power of the autotrophic biomass. The decline in heterotrophic biomass relative to autotrophic biomass resulted from the greater response of autotrophs, compared to heterotrophs, to nutrient inputs. This contrasting response resulted in a significant (ANOVA, $F=$ 7.55, $\mathrm{p}=0.00002$ ) decline in the ratio of heterotrophic to autotrophic biomass in the established planktonic communities with increasing nutrient inputs (Fig. 5).

The changes in biomass distribution within the community involved the shift from an 'inverted pyramid' distribution, indicative of a greater biomass of heterotrophs than that of autotrophs, at low nutrient inputs, to the conventional 'upward pyramid' pattern, where the biomass of autotrophs exceeds that of consumers, at the highest nutrient inputs (Figs. 6 \& 7). This biomass pyramid shift was not obvious on Day 2 (in fact, the mesocosm that had received more nutrients became more heterotrophic) but tended to stabilize after $6 \mathrm{~d}$ of incubation (Fig. 6) and lasted in a very similar form until Day 16, when some mesocosms started to slowly change. Thus, we took the average pyramid of the last 2 wk as that characterizing the steady-state system, with the steadily added nutrients. In that average pyramid, the relative biomass of protists and metazoans declined parallel to increasing nutrient inputs, remaining relatively similar to one another (Fig. 7). The greater bacterial biomass relative to that of other heterotrophs was also maintained across the broad gradient of nutrient inputs tested, with a tight linear correlation between the biomass of metazoans and heterotrophic protists and that of bacteria $(\mathrm{r}=0.93$ and 0.96 , respectively) across mesocosms.

\section{DISCUSSION}

The coastal Mediterranean community examined here was characterized by a high biomass of heterotrophs, almost double that of autotrophs, as expected from the low autotrophic biomass in these waters (Gasol et al. 1997). The community was initially domi-

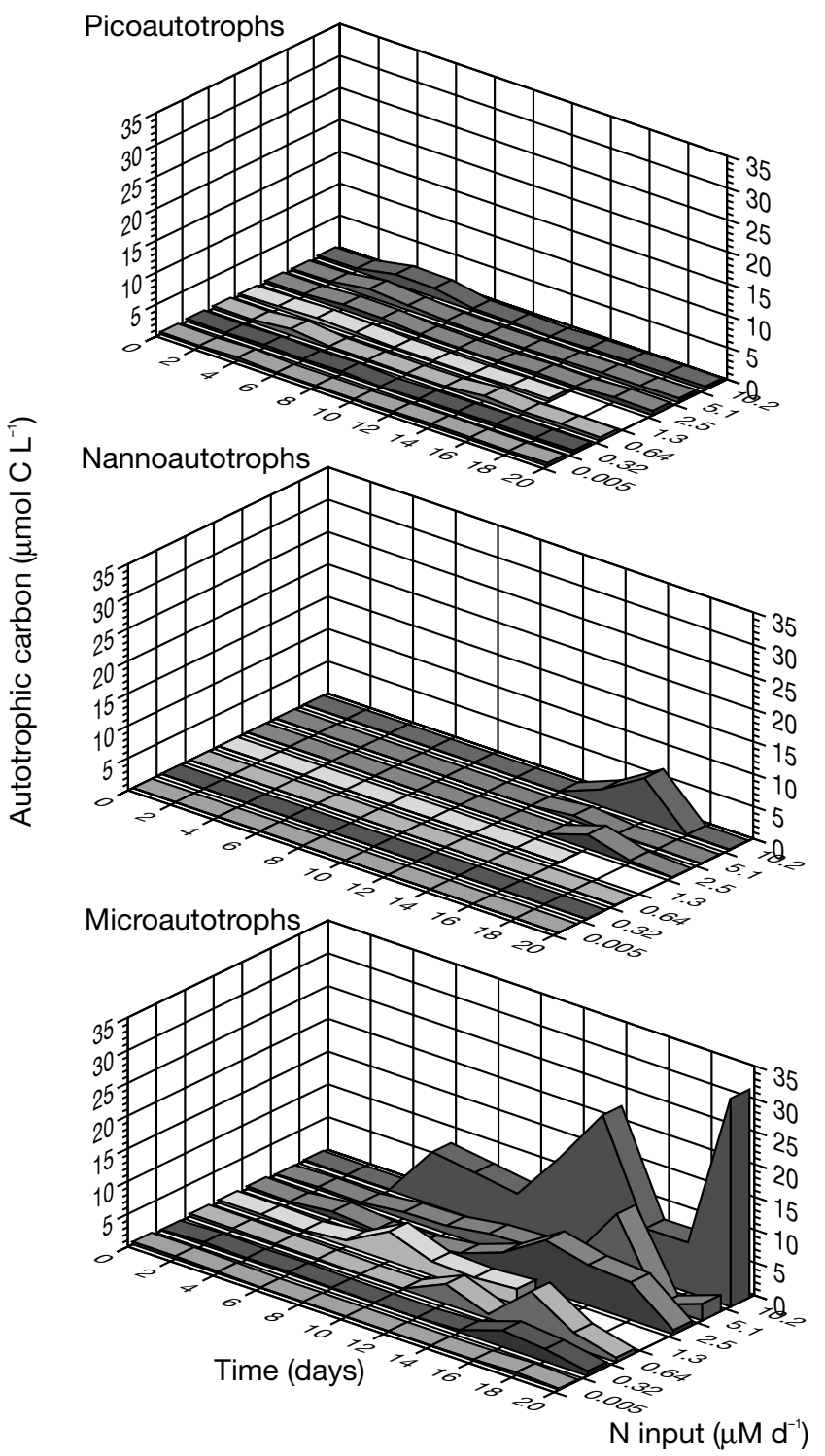

Fig. 1. Time course of the biomass of autotrophic organisms in response to increased nutrient inputs to the mesocosms 

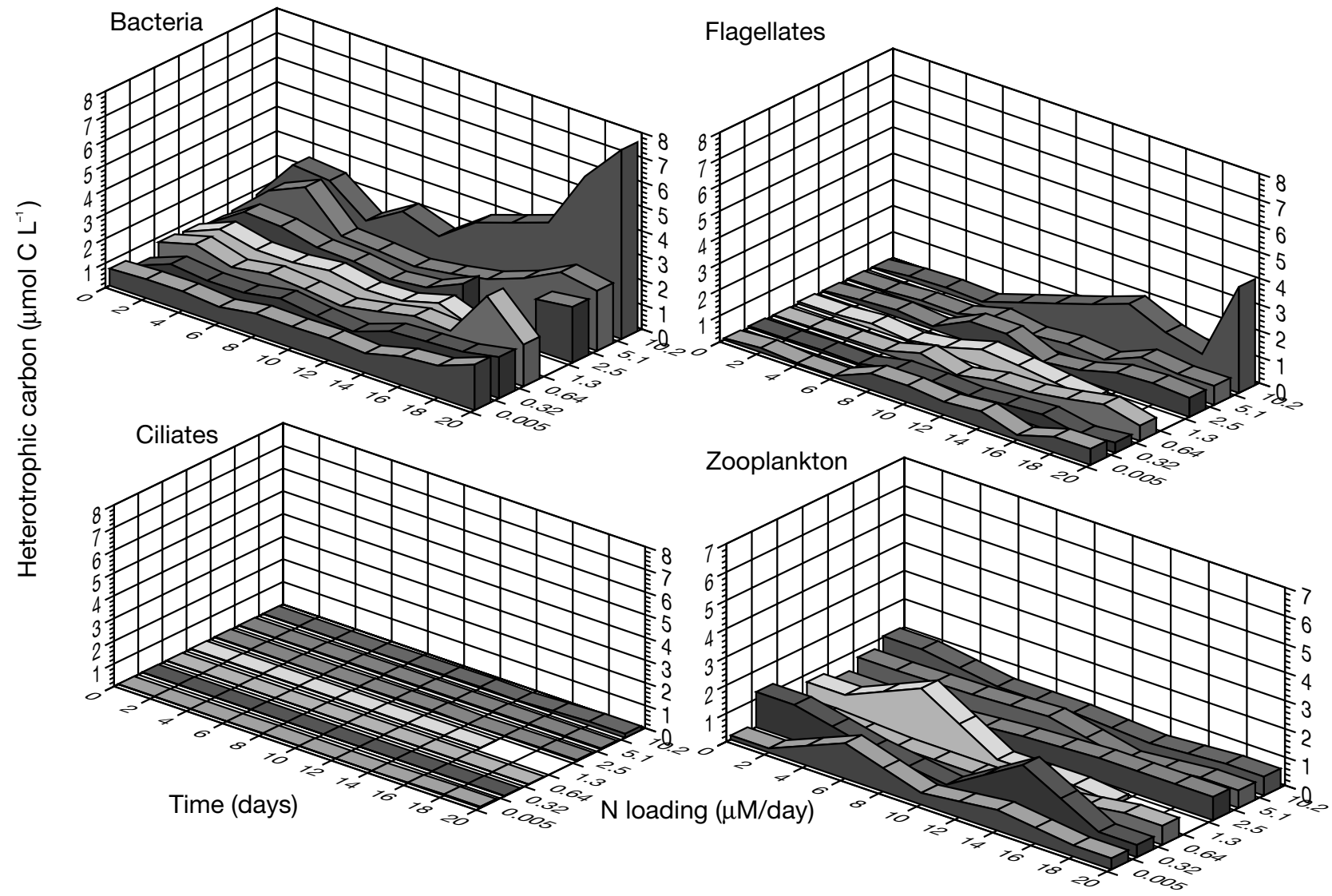

Fig. 2. Time course of the biomass of heterotrophic organisms in response to increased nutrient inputs to the mesocosms

nated by heterotrophic bacteria, but also supported a high biomass of protists and metazoan zooplankton comparable to that of autotrophs (Vaqué et al. 1997, Duarte et al. 1998, see Fig. 6)

The results of the experiment revealed a clear change in the biomass distribution within the Mediterranean planktonic community with increased nutrient inputs. Increased nutrient inputs led to an enhanced biomass of autotrophs, particularly that of microphytoplankton. Whilst the biomass of bacteria and protists also increased with increasing nutrient inputs, the increase was much more modest over the broad range of nutrient inputs tested, particularly that of protists. The biomass of metazoan zooplankton did not show any clear reactions to increased nutrient inputs, although that of particular groups, such as gelatinous forms, increased linearly with increasing nutrient inputs (Duarte unpubl. results). The reactions of the communities were equilibrated after $1 \mathrm{wk}$ of experimentation (Fig. 6), so we can consider the pyramids as the steady-state response to the added nutrients. While similar experiments have shown an initial heterotrophic phase followed by an autotrophic phase in those mesocosms that had received nutrients (e.g. Thingstad

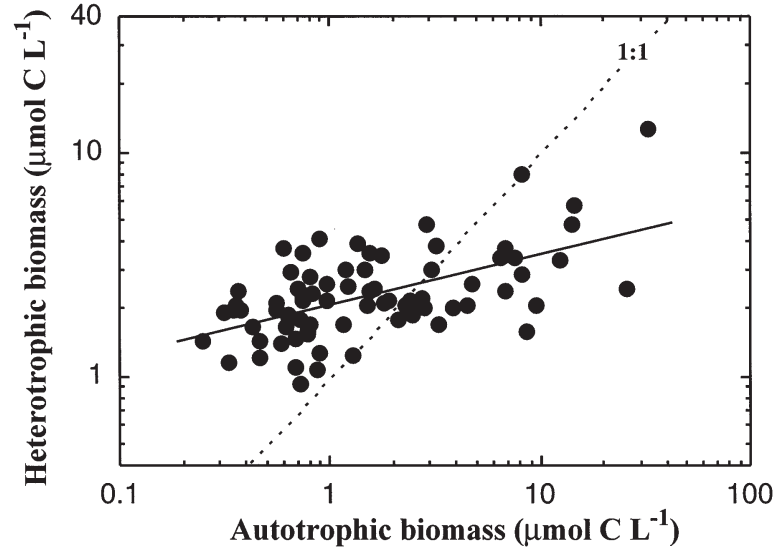

Fig. 3. Relationship between heterotrophic and autotrophic biomass in mesocosms receiving increasing nutrient inputs

et al. 1999), we observed first a short period of heterotrophy. This was perhaps related to direct nutrient stimulation of bacteria, which were later outcompeted by microphytoplankton given that $\mathrm{Si}$ was one of the added nutrients. The addition of silicate could explain the differences between the results of our experiments and those of others. 


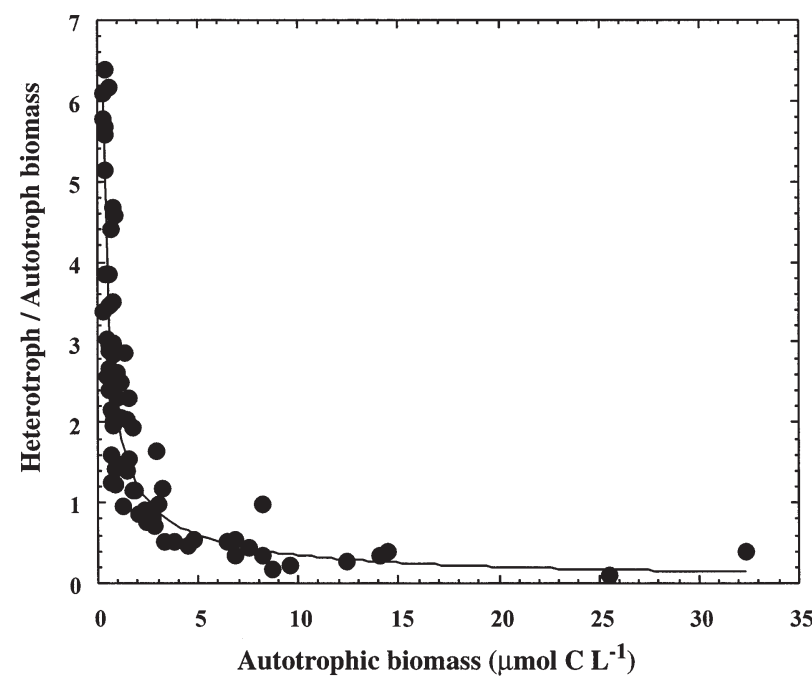

Fig. 4. Relationship between the ratio of heterotrophic/ autotrophic biomass and autotrophic biomass in mesocosms receiving increasing nutrient inputs

Despite the high combined increase in autotrophic and heterotrophic biomass, non-living organic carbon remained the dominant pool in the communities, with DOC and detrital C comprising, on average, $78 \pm 2.3$ and $18 \pm 1.7 \%$ of the organic carbon, independent of the nutrient inputs received (Fig. 8). The reason for this increase is that DOC and detrital carbon increased linearly with increasing concentration of living carbon.

The change in the biomass of heterotrophs as a result of nutrient inputs was far slower than that of

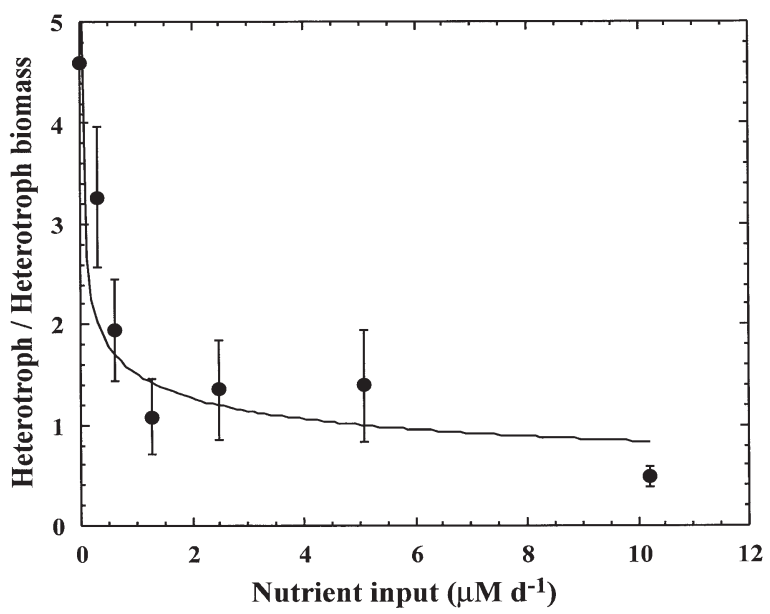

Fig. 5. Relationship between the average ratio of heterotrophic/autotrophic biomass of the planktonic communities developed after $1 \mathrm{wk}$ of nutrient inputs to the mesocosms, and the nutrient input to the mesocosms. The solid line represents the fitted regression equation (Eq. 4)

autotrophs, despite the fact that bacteria were strongly P-limited in the initial community (Duarte et al. unpubl.), which is consistent with the general pattern in Mediterranean waters (Thingstad \& Rassoulzadegan 1995, Thingstad et al. 1998, Zohary \& Robarts 1998). The $1 / 5$ power scaling between the biomass of heterotrophs and that of autotrophs is close to that derived from a comparative analysis of marine planktonic communities (Gasol et al. 1997), providing evidence that this pattern can be accounted for by differences in

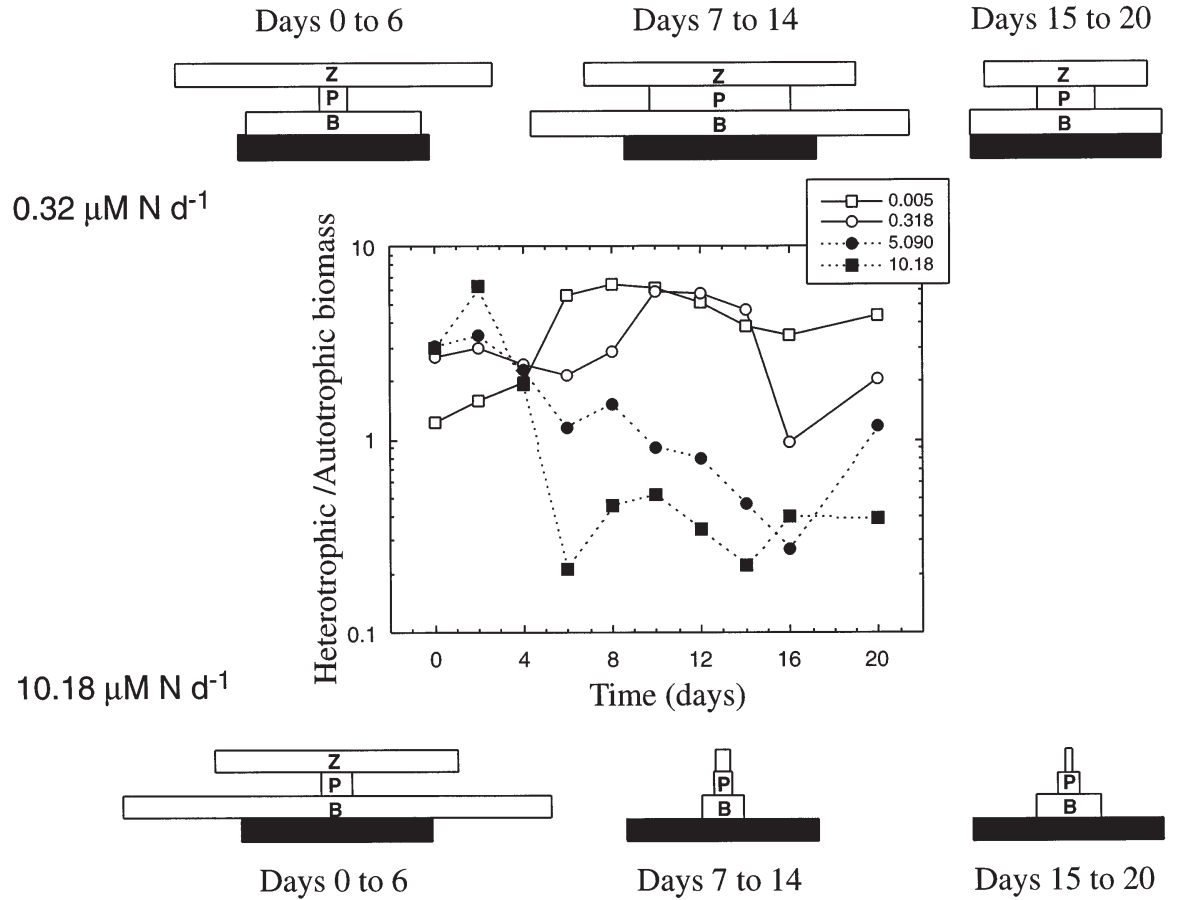

Fig. 6. Changes in the ratio heterototrophic to autotrophic biomass during the experimental period. For clarity, only 4 mesocosms are shown: that receiving no additions ( $\square)$, the control $\left(0.32 \mu \mathrm{M} \mathrm{N} \mathrm{d}^{-1}, \mathrm{O}\right)$, and those that received more nutrients $\left(5.09 \mu \mathrm{M} \mathrm{N} \mathrm{d}^{-1}, \bullet\right.$, and $\left.10.18 \mu \mathrm{M} \mathrm{N} \mathrm{d}^{-1}, \mathbf{m}\right)$. The average biomass pyramids of the mesocosms receiving 0.32 and $10.18 \mu \mathrm{M} \mathrm{N} \mathrm{d}^{-1}$ for Days 0-6, 7-14, and 15-20 are also shown. Z: zooplankton, P: protists, B: bacteria 


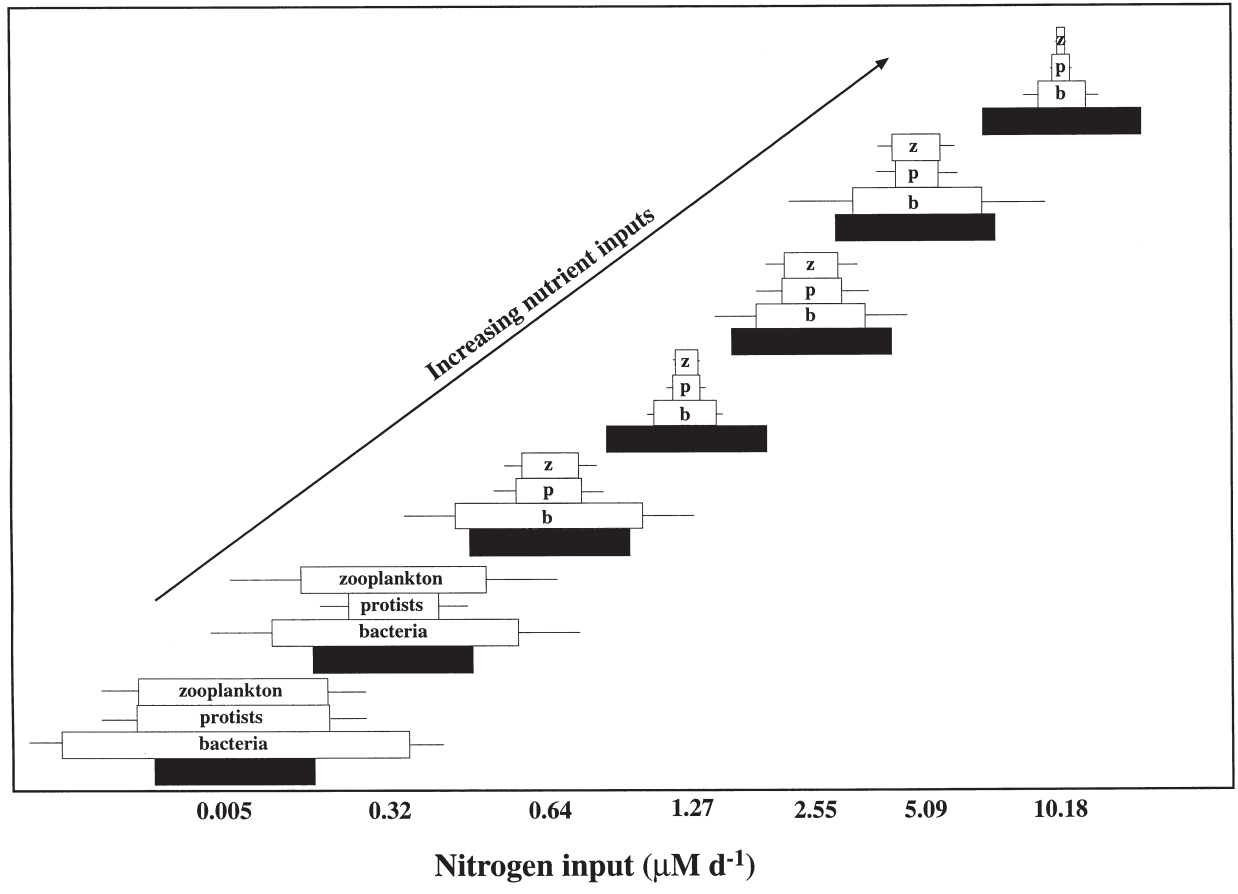

Fig. 7. Biomass distribution in the planktonic communities consolidated after $1 \mathrm{wk}$ of experimental nutrient inputs. The biomass of heterotrophs is represented (open bars) relative to that of autotrophs, represented by the black bar of constant width. Error bars represent $1 \mathrm{SE}$ about the average relative biomass over the last $13 \mathrm{~d}$ of the experiment.

nutrient supply. Indeed, the exponential decline in the ratio of heterotrophic to autotrophic biomass with increasing autotrophic carbon, derived from the community response to increasing nutrient inputs, confirms the pattern reported from a comparative analysis of ecosystems by Gasol et al. (1997). The slope of the power equation (Eq. 4) describing this decline was remarkably similar to that derived from the cross-system comparison (Gasol et al. 1997), suggesting that this pattern can be accounted for by differences in nutrient inputs among ecosystems. Hence, the hypothesis that the relative biomass distribution between heterotrophs and autotrophs is regulated by nutrient supply, which, in turn, controls autotrophic biomass, is supported by our experiment.

Hence, increasing nutrient inputs does not only regulate the biomass and production of the autotrophic component of pelagic marine ecosystems, but also results in important changes in the balance between producers and consumers. The much greater biomass of consumers at low nutrient inputs suggests that these systems must be dominated by heterotrophic processes. This has been confirmed by recent reports that the community respiration rate in unproductive marine ecosystems closely approaches or even exceeds the primary production (Duarte \& Agustí 1998). In particular, the excess bacterial biomass relative to autotrophic biomass observed at low nutrient inputs is consistent with the report that bacterial carbon demands may exceed the primary production of oligotrophic systems (del Giorgio et al. 1997).

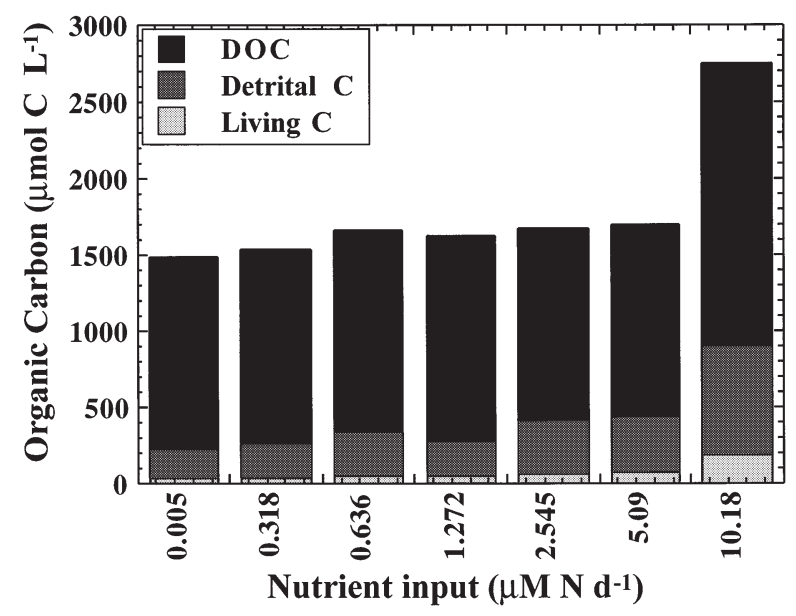

Fig. 8. Average contribution of living carbon, detrital carbon and DOC to TOC in mesocosms receiving increasing nutrient inputs over the last $2 \mathrm{wk}$ of the experiment. DOC from Duarte et al. (unpubl.) and detrital carbon was calculated as the difference between POC (from Duarte et al. unpubl.) and living $\mathrm{C}$. Values represent averages over the last $13 \mathrm{~d}$ of the experiment

When nutrient inputs are low, the biomass of autotrophs is limited, but must support a considerable carbon demand from heterotrophs, which, at the same time, play an essential role in recycling the nutrients needed to maintain the autotrophic community (Legendre \& Rassoulzadegan 1995). The grazing pressure associated with the relatively large biomass of heterotrophs under low nutrient supply may partially 
relieve the autotrophic community from nutrient limitation, although the community in our study showed clear symptoms of phosphorus limitation at low nutrient inputs. In addition, the pressure from heterotrophs also selects for autotrophic components small enough to reduce the grazing pressure they support, being, at the same time, able to maintain a fast turnover, provided nutrients are recycled efficiently by heterotrophs (Legendre \& Rassoulzadegan 1995). In contrast, the biomass of autotrophs increases so fast when nutrient inputs increase that the autotrophic community soon escapes the control of heterotrophs. What the limit is to the development of the heterotrophic community remains largely unknown, but it may include top-down controls by carnivore predators (Agustí et al. 1992).

In summary, the results presented here demonstrate conclusively that increased nutrient inputs are associated, in the Mediterranean community studied, with a shift in biomass distribution from a dominance of heterotrophs at low nutrient inputs to that of autotrophs at high nutrient inputs. The fact that the shifting balance between heterotrophic and autotrophic biomass, with increasing nutrient inputs, fitted the patterns derived from comparative analyses of marine communities, supports the notion that these differences are attributable to differences in nutrient inputs. These results support the hypothesis that recycling processes mediated by heterotrophs - must be responsible for maintaining the structure and functions of oligotrophic communities (Legendre \& Rassoulzadegan 1995), while the excess biomass of autotrophs under high nutrient inputs exceeds the capacity of the community to use their production, which either accumulates, leading to eutrophication problems, or is exported to the sediments or adjacent ecosystems. Our results confirm that the shifts in biomass structure with increasing autotrophic biomass reported for marine ecosystems reflect the role of nutrient inputs, which act, therefore, as the key factor shaping the functioning and structure of marine pelagic ecosystems.

Acknowledgements. This is a contribution to the project COMWEB, funded by the ELOISE programme of the European Commission (contract number MAS3-CT96-0045), and a grant from the Spanish Commission for Science and Technology (CICYT MAR96-1715-CE). We thank O. Moreno, E. Benavent, M. C. Sánchez, E. Razquin, D. Alonso and J. Puigdeval for assistance with biomass determinations; $\mathrm{M}$. Alcaraz and E. Saiz for useful advice; J. Seppala, T. Tamminen, and the staff at Tallers FERM (Blanes, Spain) for advice in the design and construction of the mesocosms; A. Juán Sr and Jr for assistance with the operation of the mesocosms; and the Blanes Peix Company for permission to deploy the mesocosm platform in their concession.

\section{LITERATURE CITED}

Agawin NSR, Duarte CM, Agustí S (2000) Response of Mediterranean Synechococcus growth and loss rates to experimental nutrient inputs. Mar Ecol Prog Ser 206:97-106

Agustí S, Duarte CM, Canfield DE (1992) Self-regulation, bottom-up, and top-down control of phytoplankton communities: a reply to the comment by Kamenir. Limnol Oceanogr 37:683-687

Alcaraz M, Estrada M, Flos J, Fraga F (1985) Particulate carbon and nitrogen in plankton biomass in oligotrophic and upwelling systems. Int Symp Upw W Afr Inst Invest Pesq Barcelona VI:435-448

Børsheim KY, Bratbak G (1987) Cell volume to cell carbon conversion factors for a bacterivorous Monas sp. enriched from seawater. Mar Ecol Prog Ser 36:171-175

Buck KR, Chavez FP, Campbell L (1996) Basin-wide distributions of living carbon components and the inverted trophic pyramid of the central gyre of the North Atlantic Ocean, summer 1993. Aquat Microb Ecol 10:283-298

Cushing DH, Humphrey GF, Banse K, Laevatsu T (1958) Report of the committee on terms and equivalents. Rapp Proc V ICES 144:15-16

del Giorgio PA, Bird DF, Prairie YT, Planas D (1996) Flow cytometric determination of bacterial abundance in lake plankton with the green nucleic acid stain SYTO 13. Limnol Oceanogr 41:783-789

del Giorgio PA, Cole JJ, Cimbleris A (1997) Respiration rates in bacteria exceed phytoplankton production in unproductive aquatic systems. Nature 385:148-151

Duarte CM, Agustí S (1998) The $\mathrm{CO}_{2}$ balance of unproductive aquatic ecosystems. Science 281:234-236

Duarte CM, Agustí S, Satta MP, Vaqué D (1998) Partitioning particulate light absorption: a budget for a Mediterranean Bay. Limnol Oceanogr 43:236-244

Duarte CM, Agustí S, Agawin NSR (2000) Response of a Mediterranean phytoplankton community to increased nutrient inputs: a mesocosm experiment. Mar Ecol Prog Ser 195:61-70

Elton C (1927) Animal ecology. MacMillan, New York

Gasol JM, del Giorgio PA (2000) Using flow cytometry for counting natural planktonic bacteria and understanding the structure of planktonic bacterial communities. Sci Mar (in press)

Gasol JM, del Giorgio PA, Duarte CM (1997) Biomass distribution in marine planktonic communities. Limnol Oceanogr 42:1353-1363

Holligan PM, Harris RP, Newell RC, Harbour DS, Head RN, Linley EAS, Lucas MI, Tranter PRG, Weekley CM (1984) Vertical distribution and partitioning of organic carbon in mixed, frontal and stratified waters of the English Channel. Mar Ecol Prog Ser 14:111-127

Leakey RJG, Burkill PH, Sleigh MA (1994) A comparison of fixatives for the estimation of abundance and biovolume of marine planktonic ciliate populations. J Plankton Res 16(4):375-389

Legendre L, Rassoulzadegan F (1995) Plankton and nutrient dynamics in marine waters. Ophelia 41:153-172

Norland S (1993) The relationship between biomass and volume of bacteria. In: Kemp PF, Sherr BF, Sherr EB, Cole JJ (eds) Handbook of methods in aquatic microbial ecology. Lewis Publishers, Boca Raton, p 303-307

Porter KG, Feig YS (1980) The use of DAPI for identification and enumeration of bacteria and blue-green algae. Limnol Oceanogr 25:943-948

Putt M, Stoecker DK (1989) An experimentally determined carbon: volume ratio for marine oligotrichous ciliates from es- 
tuarine and coastal waters. Limnol Oceanogr 34: 1097-1104 Simon M, Azam F (1989) Protein content and protein synthesis rates of planktonic marine bacteria. Mar Ecol Prog Ser 51:201-213

Simon M, Cho BC, Azam F (1992) Significance of bacterial biomass in lakes and the ocean: comparison to phytoplankton biomass and biogeochemical implications. Mar Ecol Prog Ser 86:103-110

Stoecker DK, Gifford DJ, Putt M (1994) Preservation of marine planktonic ciliates: losses and cell shrinkage during fixation. Mar Ecol Prog Ser 110:293-299

Strathmann R (1967) Estimating the organic carbon content of phytoplankton from cell volume or plasma volume. Limnol Oceanogr 12:411-418

Thingstad TF, Rassoulzadegan F (1995) Nutrient limitations, microbial food webs, and 'biological C-pumps': suggested interactions in a P-limited Mediterranean. Mar Ecol Prog Ser 117:299-306

Thingstad TF, Zweifel UL, Rassoulzadegan F (1998) P limitation of heterotrophic bacteria and phytoplankton in the northwest Mediterranean. Limnol Oceanogr 43:88-94

Thingstad TF, Pérez M, Pelegrí S, Dolan J, Rassoulzadegan F

Editorial responsibility: Otto Kinne (Editor),

Oldendorf/Luhe, Germany
(1999) Trophic control of bacterial growth in microcosms containing a natural community from northwest Mediterranean surface waters. Aquat Microb Ecol 18:145-156

Uye S, Iwamoto N, Ueda T, Tamaki H, Nakahira K (1999) Geographical variations in the trophic structure of the plankton community along a eutrophic-mesotrophic-oligotrophic transect. Fish Oceanogr 8:227-237

Vaqué D, Blough HA, Duarte CM (1997) Dynamics of ciliate biomass and community structure in an oligotrophic coastal environment (NW Mediterranean). Aquat Microb Ecol 12:71-83

Verity PG, Langdon C (1984). Relationships between lorica volume, carbon, nitrogen, and ATP content of tintinnids in Narragansett Bay. J Plankton Res 6:859-868

Waterbury JB, Watson SW, Valois FW, Franks DG (1986) Biological and ecological characterisation of the marine unicellular cyanobacterium Synechococcus. In: Platt T, Li WKW (eds) Photosynthetic picoplankton. Can Bull Fish Aquat Sci 214:71-120

Zohary T, Robarts RD (1998) Experimental study of microbial $P$ limitation in the eastern Mediterranean. Limnol Oceanogr 43:387-395

Submitted: September 13, 1999; Accepted: March 16, 2000 Proofs received from author(s): October 9, 2000 